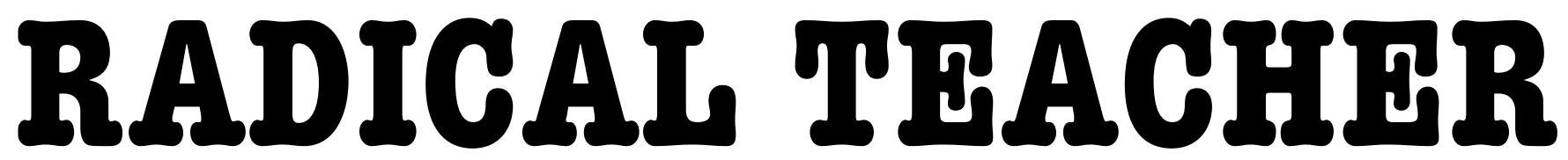

A SOCIALIST, FEMINIST, AND ANTI-RACIST JOURNAL ON THE THEORY AND PRACTICE OF TEACHING

\title{
Pink Triangles
}

(RADICAL TEACHER NO.23, 1983)

by Cathy Hoffman and Diane Raymond

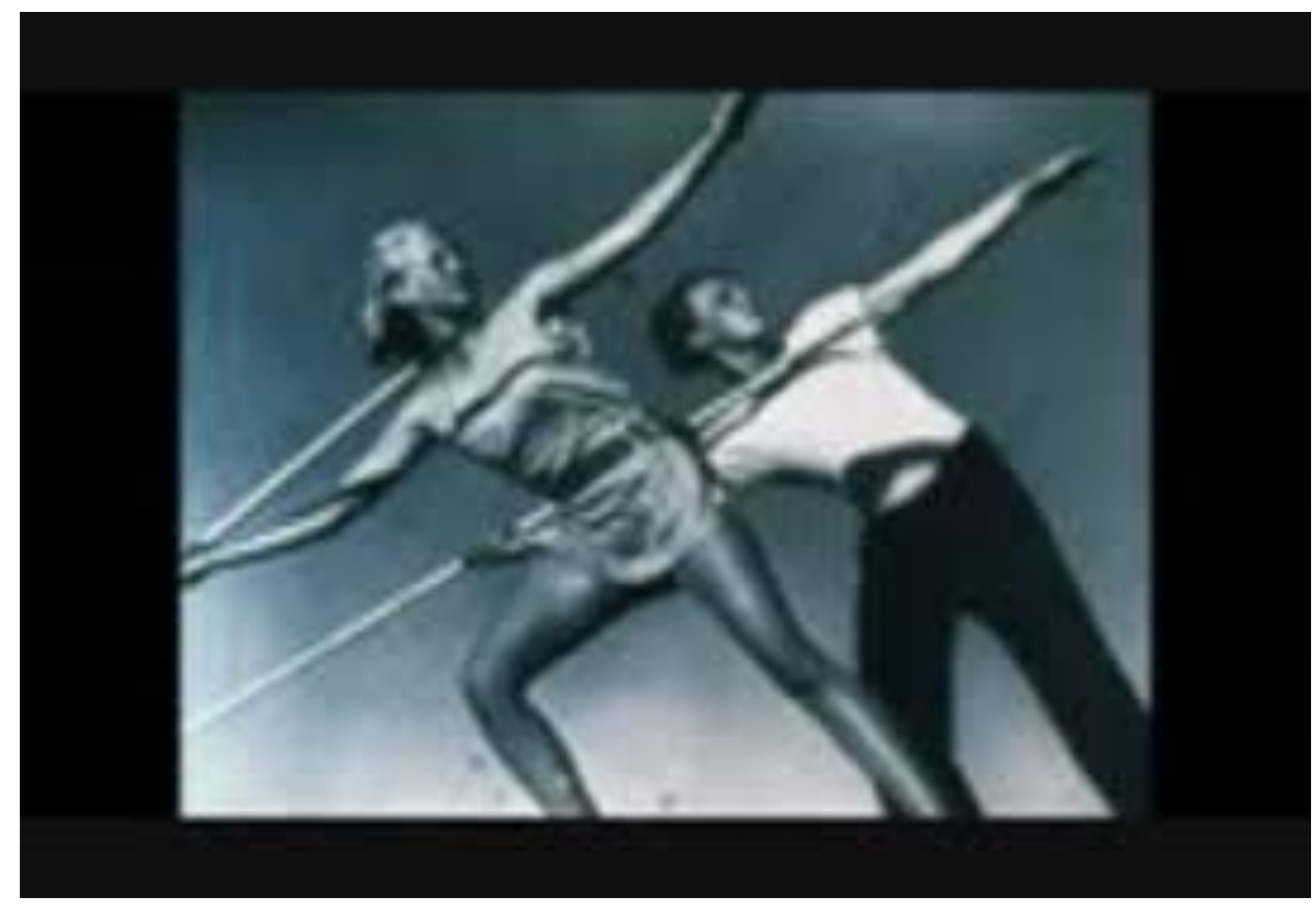

PINK TRIANGLES (CAMBRIDGE DOCUMENTARY FILMS, 1982) 
Pink Triangles. Directed by Margaret Lazarus and Renner Wunderlich. 34 minutes. With Study Guide.

$P$

ink Triangles is a wonderful documentary which looks at the experiences and history of gay men and lesbians from a political angle. It tries to unravel the texture and causes of homophobia. Through interviews, onthe-street commentary, and footage from the 1930s and 1950 s, this film documents the oppression of gay men and lesbians and suggests some connections between the treatment of gay people and other "minorities." There are particularly moving scenes from the Nazi concentration camps and interviews with Moral Majority leaders who call for the introduction of capital punishment for the homosexual.

This film is useful in several different contexts. It is obviously appropriate for any course which touches on homosexuality and lesbianism. It is also useful for raising questions about the nature of prejudice and the fascist nature of a state which dictates political and sexual conformity.

A Study Guide which accompanies the film is designed to help the teacher round out discussion or create a larger unit on issues relating to homosexuality and homophobia. The Guide also contains exercises which may help the instructor motivate more personal discussion.

The film has been used at Bentley College in several philosophy courses, including one on feminism and an introductory course with a section on sexual morality and stereotyping. Students generally believe that they are more "liberal" than the people interviewed in the film, and they are usually shocked and moved when the ensuing discussion quickly elicits their own homophobia. The instructor should take advantage of the broader political message of the film, for students do not often have the opportunity to tie together discussions of race, class, and sex oppression in the way that Pink Triangles does; though they frequently balk at such analyses, students cannot help but be struck by the similarities. Given more class time, one could use this film in conjunction with, for example, The Word Is Out, which looks at the individual lives of twelve gay men and lesbians.

Pink Triangles is an important film. It forces each of us to examine our own homophobia and its sources; with the rise of the "New Right" and its agenda of repression, there is no more pressing time for such an examination.

(c) EY-NG-ND

ULIS D-Sork
This work is licensed under a Creative Commons Attribution-Noncommercial-No Derivative Works 3.0 United States License.

This journal is published by the University Library System of the University of Pittsburgh as part of its D-Scribe Digital Publishing Program, and is cosponsored by the University of Pittsburgh Press. 